\title{
Impact of siRNA transfection on tumor development under experimental pathology of thyroid gland
}

\author{
V. M. Zaporozhan, G. S. Maryniuk, O. L. Kholodkova, \\ V. V. Bubnov, D. U. Andronov \\ The Odessa National Medical University, Ukraine \\ 2, Valihovskyy Str., Odessa, Ukraine, 65082 \\ a_borshchenko@ukr.net; kholodkova_1@rambler.ru
}

\begin{abstract}
Aim. To assess the impact of siRNA transfection on the tumor development under experimental pathology of the thyroid gland. Methods. Experiments were performed on rats weighing $180 \pm 20 \mathrm{~g}$, which were divided into five groups: $I A$ and IB - animals with simulated hypo- and hyperthyroid states and transplanted Guerin's carcinoma; IIA and IIB - animals with simulated hypo- and hyperthyroid states and transplanted Guerin's carcinoma in combination with siRNA transfection; III - control group with transplanted Guerin's carcinoma in combination with siRNA transfection. Orthogonal dimensions of the tumor were measured. Histological and immunohistochemical researches of tumor samples were performed. Results. It has been shown that the inhibitory effect of short interfering RNA is realized to a greater extent in the hypothyroid state, indicating an important role of thyroid hormones in the regulation of expression of genes that control the cell cycle. We discuss a possible dependence of necrobiotic processes prevalence and characteristic changes in the blood vessels on the effects of thyroid hormones on angiogenesis and proliferative processes. Conclusions. siRNA trasfection leads to inhibition of tumor growth in animals with both hypo- and hyperthyroidism, but it is more pronounced at hypothyroidism.
\end{abstract}

Keywords: transfection, siRNA, experimental model, hypothyroidism, hyperthyroidism.

Introduction. Some authors consider the influence of T-helper subpopulations and other immune cells to be the basic mechanisms of the thyroid hormone (TH) action along with direct stimulation of cancerogenesis [1]. Thyroxine regulates the functioning of tyrosine protein and plays a significant role in apoptosis [2]. Thus, the functional state of the thyroid gland is an important predictor of clinical outcome of tumors.

There has been recently detected a possibility of the gene expression inhibition based on the creation of double-stranded RNA (dsRNA) molecules. Using these dsRNA enables target exclusion of individual genes without violation of the formation of neighboring genes' proteins; this method being more effective and fast than any other. This phenomenon is called RNA interfe-

(C) Institute of Molecular Biology and Genetics, NAS of Ukraine, 2013 rention; the dsRNA-sequence that contributes to it is called siRNA (short interfering RNA).

siRNA does not prevent gene readouts but includes the typical cell mechanism blocking the transcription of gene mRNA and prevents the formation of a corresponding protein (post-transcriptional gene signalling).

Nonspecific siRNA binding with genes is an important issue for researchers and clinicians who use them for gene expression inhibition. However, no proper attention has been paid to the application of tumor growth epigenetic modifications with thyroid dysfunction in experimental models of low-differentiated tumors [3-5].

The SOCS family proteins form a]part of the classical negative feedback system that regulates cytokine signal transduction. SOCS1 is involved in negative regulation of cytokines that signal through the JAK/ 
STAT3 pathway. Through binding to JAKs, SOCS1 inhibits their kinase activity and suppresses the Tec protein-tyrosine activity in vitro. There are known some siRNA modulating the SOCS1 gene expression, e. $g$. hsa-miR-411, hsa-miR-142-5p, hsa-miR-30c, hsa-miR379*, hsa-miR-331-3p, hsa-miR-548v, hsa-miR-30d, hsa-miR-221, however their effects on the dynamics of tumor growth in the conditions of disorders of thyroid gland functions have been never investigated.

The aim of the study was to assess an impact of siRNA transfection on the tumor development under experimental pathology of the thyroid gland.

Materials and methods. Experiments were conducted on 32 white female laboratory rats weighing $180 \pm$ $\pm 20 \mathrm{~g}$, which were kept on a vivarium standard diet. Guerin's carcinoma $(0.5 \mathrm{ml}$ suspension of tumor cells $(5-6) \cdot 10^{6}$ cells $/ \mathrm{ml}$ ) was transplanted to the animals of I group $(n=12)$ by subcutaneous injection in the back between the shoulders. These cells were obtained from donor rats (tumor strain was provided by R. E. Kavetsky Institute of Experimental Pathology, Oncology and Radiobiology, NAS of Ukraine). To the animals of II group $(n=12)$ the tumor cells were administered along with siRNA transfection according to the same method [6].

Each group was divided into two subgroups (A and B) depending on the functional state of thyroid gland. The hypothyroid state (subgroups IA and IIA) was simulated by blocking the thyroid hormones secretion by mercazolil that was administered one time per day at a dose of $5 \mathrm{mg}$ per $100 \mathrm{~g}$ body weight intragastric within two weeks. The hyperthyroid condition (subgroups IB and IIB) was modeled by the L-thyroxine intragastric administration 1 time per day at a dose of $50 \mathrm{mg}$ per $100 \mathrm{~g}$ body weight for two weeks. There was also assessed the dynamics of tumor growth amongst the animals (III or control group, $n=8$ ) receiving siRNA without changing the functional state of thyroid gland.

To obtain the tumor suspension we preliminary selected some cells of the tumor by its incubation with collagenase (with concentration $1 \mu \mathrm{l} / \mathrm{ml}$ ) for $1 \mathrm{~h}$ at $37^{\circ} \mathrm{C}$. Afterwards, an additional splitting of the tumor cells was done with the automated system for mechanical tissue disaggregation «BD Medimachine» (Germany). The tumor cells were filtered with a syringe through the cap Steri-Dual (3 M «Health Care» (Germany)). Next, the cells were counted in the Goryaev's chamber. Then
RPMI 1640 medium was added up to the concentration of $(5-6) \cdot 10^{6}$ cells $/ \mathrm{ml} .0 .5 \mathrm{ml}$ of the received tumor suspension was administered subcutaneously to the rats of the Group IA and IIB.

The transfection mixture was prepared separately. $100 \mu 1$ DMEM medium with high glucose concentration was added to a sterile tube with $4 \mu \mathrm{l}$ of transfection reagent Turbofect R-0537 («Fermentas», Lithuania) and then the diluted transfection reagent was kept at room temperature for 10-20 min. The diluted transfection reagent was added with $1 \mu 1$ siRNA («Dharmacon», USA, P-011511-07-0005 siRNA, human SOCS1). Then they were gently stirred with a pipette, and incubated at room temperature for 10-20 min to form transfection complexes. The obtained mixture was diluted with $500 \mu 1$ of culture medium RPMI 1640. Then the culture medium was aspirated from the tumor cells and immediately replaced with a mixture of the diluted reagent of transfection.

In 20-30 min the rats of Group IIA and IIB were inoculated with the tumor cells with siRNA.

Within 21 days the development of the tumors in the experimental rats was observed. Then animals were decapitated under a mild chloroform anesthesia. The specimens were stained with hematoxylin and eosin and analyzed with optical microscope Leica DM750 (Germany) with photo-video output, camera (5 M pixels).

We carried out immunohistochemical studies of proliferation marker $\mathrm{Ki}-67$. Proliferation index was calculated as the proportion of positively stained nuclei of tumor cells within the proliferative compartment in 5 randomly selected fields of view (> 500 cells) $[7,8]$.

Statistical analysis was performed using the software Statistica 6.15 («StatSoft Inc.», USA) [9].

Results and discussion. The siRNA transfection which is the specific inhibition of endogenous genes significantly affected the tumor growth dynamics (Table).

It could be concluded that siRNA transfection reduced tumor growth in hypothyroid rats by $25.5 \%$, while the tumor growth in hyperthyroid status decreased only by $3.5 \%$. This makes possible to assume the thyroid hormone ability to block siRNA inhibitory effect.

During the histological examination of tumors derived from experimental animals with simulated hypothyroid state it was found that the tumor areas consisted of polymorphic cells with the signs of glandular epithelium, large hyperchromatic nucleus, coarse chromatin, 
Dynamics of tumor growth (cm3) in the experimental groups $(M \pm m)$

\begin{tabular}{|c|c|c|c|c|c|}
\hline \multirow{2}{*}{ Group } & \multicolumn{5}{|c|}{ Days of the experiment } \\
\hline & 9 & 12 & 15 & 18 & 21 \\
\hline IA & $2.38 \pm 0.15^{*}$ & $7.76 \pm 0.37 *$ & $15.82 \pm 0.55^{*}$ & $18.77 \pm 0.61 *$ & $21.39 \pm 0.41^{*}$ \\
\hline IB & $2.6 \pm 0.13^{*}$ & $6.22 \pm 0.25 *$ & $12.92 \pm 0.45^{*}$ & $17.35 \pm 0.39 *$ & $19.22 \pm 0.74^{*}$ \\
\hline IIA & $1.71 \pm 0.08$ & $5.5 \pm 0.15$ & $8.02 \pm 0.25^{*}$ & $11.41 \pm 0.44$ & $15.92 \pm 0.48$ \\
\hline IIB & $1.62 \pm 0.14$ & $5.18 \pm 0.17$ & $9.5 \pm 0.31$ & $14.83 \pm 0.64$ & $18.53 \pm 0.72$ \\
\hline III (control) & $1.78 \pm 0.09$ & $5.18 \pm 0.17$ & $10.72 \pm 0.41$ & $13.5 \pm 0.46$ & $16.52 \pm 0.48$ \\
\hline
\end{tabular}

Note. $*$ The difference with the control group is statistically significant $(\mathrm{P}<0.05)$.

homogenous eosinophilic cytoplasm and clear outlines. A shape of nuclei was uneven with indrawings. Tumor cells were located separately, their nuclei were displaced to the periphery. Large areas of destroyed cells with nuclei lysis were observed among the tumor tissue, as well as the fragments of dead cells, dramatically dystrophic granulocytes. Necrosis occupied approximately $1 / 3$ of the investigated tumor area. Eosinophils dominated over granulocytes. Outgrowth contacts with the formation of lace like structures between the tumor cells were found in the areas with a more compact arrangement of tumor cells. These cells had an amphiphilic cytoplasm, their borders were uneven. A large number of capillaries with flattened endothelium were observed among the tumor tissue. Necrosis of tumor cells was observed in nonvascular and pericapillary space.

After the siRNA transfection in tumor tissue of hypothyroid rats, destroyed cells with nuclei lysis, cellshading, fibrin strands and mixed dystrophic granulocytes were frequently found among the fragments of dead cells. Necrosis of tumor cells also was observed in non-vascular and pericapillary space (Fig. 1, see inset).

On the other hand, somewhat different picture was observed in the hyperthyroid state. In a histological section of the encapsulated tumor site which consisted of large polymorphic cells with signs of glandular epithelium and large hyperchromatic nucleus there were different variants of the nuclei location: from central to fully displaced to the periphery. The nuclei had a coarse chromatin with the presence of 1-3 large nucleoli. The shape of most nuclei was smooth, concave-oval. The cells contained homogeneous amphiphilic cytoplasm with clear boundaries. The tumor cells were placed separate- ly at greater area, they had a nucleus shifted to the periphery. There were observed the outgrowth contacts with the formation of lace like and perivasculary palisade like structures between the tumor cells. Among the tumor tissue there were also found small line areas of destroyed tumor cells with nuclei lysis, the fragments of necrotic cells mixed with sharply dystrophic granulocytes and the fragments of necrotic granulocytes. The necrosis fields occupied about $1 / 5$ of all the investigated tumor area. At the level of tumor cells with necrosis there were a small number of isolated convex-oval tumor cells with the eccentric rounded nucleus and eosinophilic cytoplasm. There were large number of capillaries with flattened endothelium.

After application of siRNA transfection of animal's tumor at hyperthyroidism we observed slightly different histological figure (Fig. 2, see inset). There were dominated the areas with relatively compact arrangement of tumor cells with outgrowth contacts and the formation of lace like structures. The cytoplasm of tumor cells was amphiphilic. The boundaries of cells were uneven and with outgrowing. Parts of the nuclei had a rough form with indrawings. Other areas consisted of separately located polymorphic cells with a large hyperchromic nucleus. Nucleus was shifted to the periphery. It was defined a coarse chromatin and a homogeneous eosinophilic cytoplasm with clear bounds. There were also observed the fields of destroyed cells with nuclei lysis, falling out of fibrin strands and admixture of dramatically dystrophic granulocytes among the fragments of dead cells. Besides, there were the following changes: the compact areas of tumor cells changed to more isolated and then to necrosis. A large number of capillaries were 
Figures to article by V. M. Zaporozhan et al.
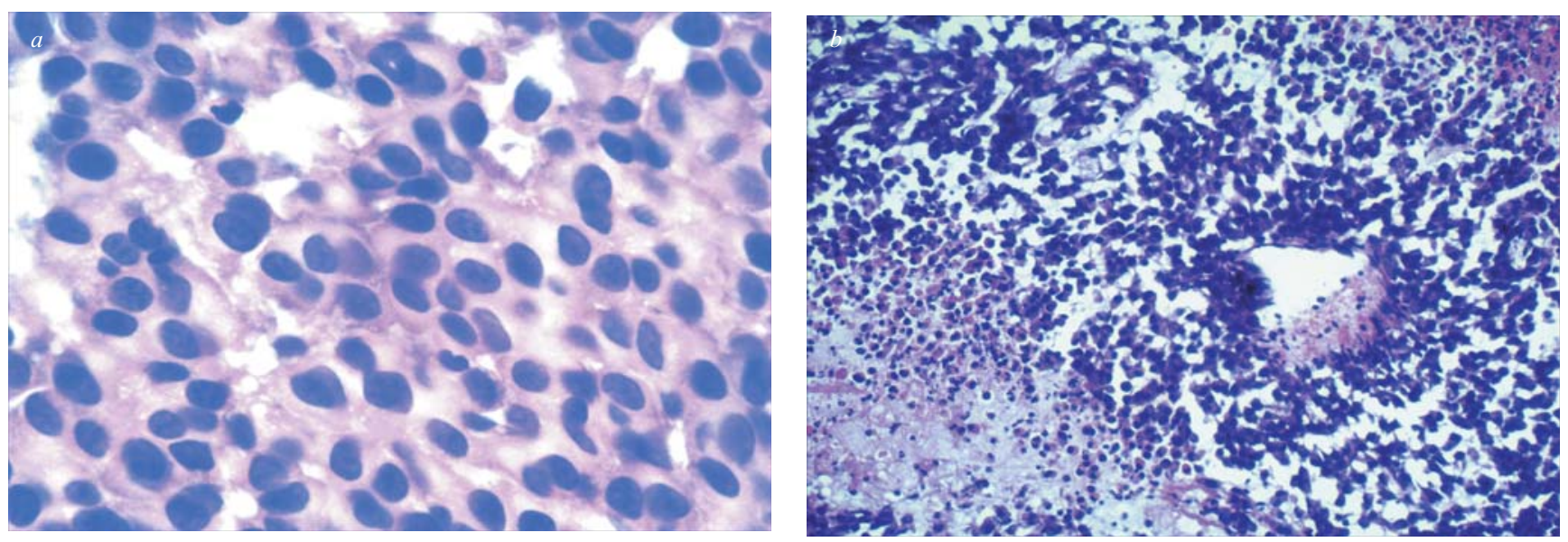

Fig. 1. Histology of the modified pathomorphosis in a hypothyroid state: $a$ - without the siRNA transfection, $\times 400$; $b-$ with the siRNA transfection, $\times 200$. Hematoxylin-eosin

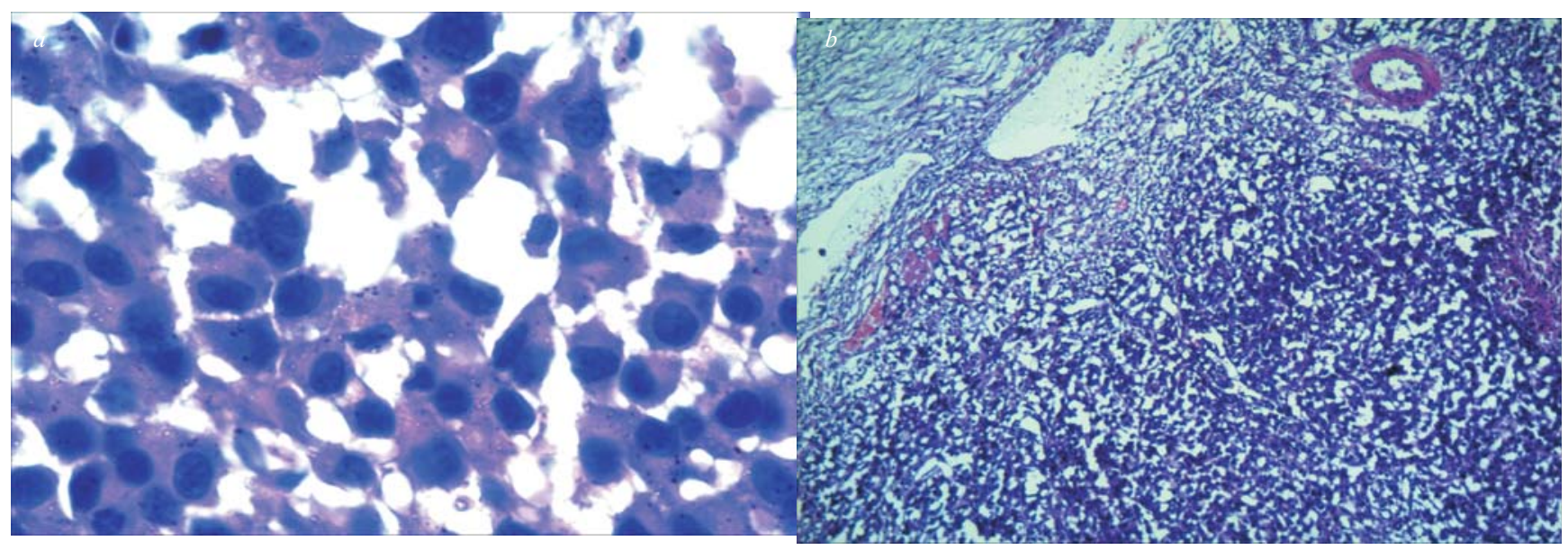

Fig. 2. Histology of the modified pathomorphosis in a hyperthyroid state: $a$ - without the siRNA transfection, $\times 400 ; b-$ with siRNA transfection, $\times 100$. Hematoxylin-eosin 
among the tumor, some of them had blood stasis and mixed thrombi without evidence of organization. The total volume of necrosis was about $1 / 4$ of the total tissue, necrosis fields were larger in the depth of tumor site and lesser - under the capsule of connective tissue. The border of the tumor with the granulation tissue was clear.

The index of tumor cells proliferation in femalerats with simulated hypothyroidism in the group IA was $14.4 \%$, whereas in the group IIA it was only $5.6 \%$. The proliferation index has not changed after siRNA transfection introduction in the model of experimental hyperthyroidism: in the IB group it was $10.3 \%$, and in IIB $-9.6 \%(p>0.05)$.

While studying oncogenesis much attention has been recently paid to the signal transducer and activator of transcription 3 (STAT3). STAT3 is classified as a proto-oncogene because its activated form can mediate oncogenic transformation in cells culture and induce the formation of tumors [10]. Several studies have shown that STAT3 is activated in many cancers, such as leukemia, gliomas, cancer of the head and neck, melanoma, breast cancer, prostate cancer, cervical cancer, endometrial cancer [11]. Tyrosine kinases Jak2, onkoprotein Src and vascular endothelial growth factor (VEGF) are potential activators of STAT3. Abnormally activated STAT3 activates a number of genes which manage the behavior of tumor cells (survival ability, growth, angiogenesis, invasion and resistance to immune oversight).

The suppressor of cytokine signaling (SOCSI) is one of the genes which can reduce the tyrosine kinase activity and block Jak2 leading to the inhibition of STAT3 phosphorylation [12]. Activation of SOCS1 is influenced by cytokines. This gene inhibits hormonal signals and suppresses cytokine signals acting via the intracellular negative feedback reducing the activity of tyrosine kinase Jak connected with the receptor [12].

There is information that siRNA also can inhibit proliferation and increase apoptosis as a result of interruption of STAT3 phosphorylation through reducing regulatory Jak2 activation [13]. siRNA also suppresses the expression of VEGF, which regulates angiogenesis, and the tumor immune response in cancer. As a result of this interaction, the tumor cell proliferation decreases, apoptosis and expression of both mature and immature markers of dendritic cells (HLA-DR, CD80, CD86, CD40, CD1a, CD83) increase [14].
Thus, the results obtained strongly prove that the tumor inhibition effect of small interfering RNA takes place to a greater extent at hypothyroid state than at hyperthyroidism. This phenomenon indicates an important role of thyroid hormones in the regulation of the genes expression, which controls the cell cycle. According to the literature data [15], we can make an assumption that thyroxine activates the proliferation of tumor cells more than their apoptosis. The prevalence of necrobiotic processes and characteristic changes in the blood vessels may be associated with the specific effects of thyroid hormones on angiogenesis.

In addition to the gene expression inhibition, one more interesting property of siRNA is the ability to trigger independently an immune response - to activate alpha- and beta-interferons, cytokines and other mediators of inflammation [16].

So, besides the ability to suppress the expression of genes which trigger tumor development, siRNA can also directly activate the expression of SOCS1 gene and induce antitumor immune response. This property provides siRNA a great potential to be used in genetic therapy of cancer.

Conclusions. After inoculation of Guerin's carcinoma to female-rats with simulated hypo- and hyperthyroidal states the proliferation of tumor cells is more active in the group of animals with experimental hypothyroidism.

The siRNA trasfection leads to the inhibition of tumor growth in animals with both hypo- and hyperthyroidism, but this process is more active at hypothyroidism.

The prospects for further research are associated with assessment of a possibility to use siRNA transfection for control and activation of apoptosis in an experimental model of tumorogenesis.

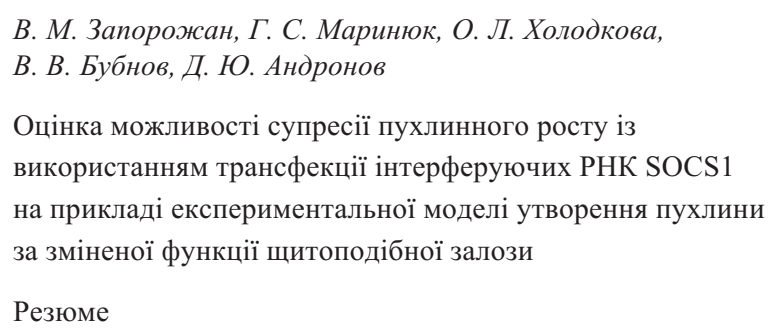

Мета. Оиінити вплив трансфекиійно введеної sіРНК на розвиток пухлини за умов експериментальної патологї шитоподібної залози. Методи. Експерименти виконували на самииях иурів масою 
$180 \pm 20$ г. Тварин розділено на n'ять груп: ІА і ІБ-щури з модельованими гіпо- $i$ гіпертиреозом та перевитою каричномою Герена, IIA і ІІБ - з модельованими гіпо- $i$ гіпертиреозом та перевитою карииномою Герена у комплексі з трансфекиійно введеною siPHK, III - з перевитою карииномою Герена у комплексі з трансфекиійно введеною sіРНК. Вимірювали ортогональні розміри пухлини. Проводили гістологічні та імуногістохімічні дослідження зразків пухлини. Результати. Показано, щчо інгібувальний вплив коротких інтерферуючих РНК більшою мірою проявляється за гіпотиреоїдного стану, щзо свідчить про важливу роль гормонів щзитоподібної залози у регулячії експресї генів, контролюючих клітинний цикл. Обговорюється ймовірність залежності переважання некробіотичних проиесів та характерних змін у судинах від дії тиреоїдних гормонів на ангіогенез і проліферативні процеси. Висновки. Трасфекиія sіРНК призводить до пригнічення пухлинного росту у тварин як з гіпо-, так $і$ з гіпертиреозом, проте активніше ией процес протікає при гіпотиреоїдому стані.

Ключові слова: трансфекція, sіРНК, експериментальна модель, гіпотиреоз, гіпертиреоз.

В. М. Запорожан, А. С. Маринюк, Е. Л. Холодкова, В. В. Бубнов, Д. Ю. Андронов

Оценка возможности супрессии опухолевого роста с использованием трансфекции интерферирующих PHK SOCS1 на примере экспериментальной модели образования опухоли при измененной функции щитовидной железы

\section{Резюме}

Цель. Оиенка влияния трансфекиионно введенной siРНК на развитие опухоли в условиях экспериментальной патологии щчитовидной железы. Методы. Эксперименты проводили на самках крыс массой $180 \pm 20$ г. Животных разделили на пять групп: IА и ІБ - крысы с моделированными гипо- и гипертиреозом и перевитой карииномой Герена, ІІА и ІІБ - с моделированньми гипо- и гипертиреозом и перевитой карииномой Герена в комплексе $c$ трансфекционно введенной siРНК, III - контрольная группа с перевитой карииномой Герена в комплексе с трансфекиионно введенной sіРНК. Измеряли ортогональные размеры опухоли. Осуще ствляли гистологические и иммуногистохимические исследования образиов опухоли. Результаты. Показано, что ингибирующее влияние коротких интерферирующих РНК в большей степени проявляется при гипотиреоидном состояния, что указывает на важную роль гормонов щитовидной железы в регуляции экспрессии генов, контролирующих клеточный цикл. Обсуждается вероятность зависимости преобладания некробиотических процессов и характерных изменений в сосудах от влияния тиреоидных гормонов на ангиогенез и пролиферативные проиессы. Выводы. Трансфекиия sіРНК приводит к угнетению опухолевого роста у животных как с гипо-, так и с гипертиреозом, однако более активно этот процесс протекает при гипотиреоидного состоянии.

Ключевые слова: трансфекиия, sіРНК, экспериментальная модель, гипотиреоз, гипертиреоз.

\section{REFERENCES}

1. Brent G. A. Mechanisms of thyroid hormone action // J. Clin. Invest.-2012.-122, N 9.-P. 3035-3043.
2. Sar P., Peter R., Rath B. Das Mohapatra A., Mishra S. K. 3, 3'5 Triiodo $\mathrm{L}$ thyronine induces apoptosis in human breast cancer MCF-7 cells, repressing SMP30 expression through negative thyroid response elements // PLoS One.-2011.-6, N 6.-e20861.

3. Khatri N., Rathi M., Baradia D., Trehan S., Misra A. In vivo delivery aspects of miRNA, shRNA and siRNA // Crit. Rev. Ther. Drug. Carrier. Syst.-2012.-29, N 6.-P. 487-527.

4. Zhou J., Bobbin M. L., Burnett J. C., Rossi J. J. Current progress of RNA aptamer-based therapeutics // Front. Genet.-2012.3.-P. 234.

5. Chaturvedi K., Ganguly K., Kulkarni A. R., Kulkarni V. H., Nadagouda M. N., Rudzinski W. E., Aminabhavi T. M. Cyclodextrin-based siRNA delivery nanocarriers: a state-of-the-art review // Expert. Opin. Drug. Deliv.-2011.-8, N 11.-P. 1455-1468.

6. McNaughton B. R., Cronican J. J., Thompson D. B., Liu D. R. Mammalian cell penetration, siRNA transfection, and DNA transfection by supercharged proteins // Proc. Natl Acad. Sci. USA.-2009.-106, N 15.-P. 6111-6116.

7. Baudarbekova M. M. Ki-67 that PCNA expression in hyperplastic states and adenocarcinoma of the endometrium in women of perimenopauzal condition // Oncology.-2010.-12, N 4.-P. 394.

8. Zak M. U. Cell renewal in the gastric mucosa in patients with chronic atrophic gastritis // Contemporary Gastroenterology.2011.-2, N 58.-P. 27-32.

9. Borovikov O. P. STATISTICA: the art of analyzing data on a computer $\left(2^{\text {nd }}\right.$ ed.).-Moscow: Science, 2007.-700 p

10. Chen C. L., Hsieh F. C., Lieblein J. C. Brown J., Chan C., Wallace J. A., Cheng G., Hall B. M., Lin J. Stat3 activation in human endometrial and cervical cancers // Br. J. Cancer.-2007.-96, N 4.P. 591-599.

11. Liu J., Xu X., Feng X., Zhang B., Wang J. Adenovirus-mediated delivery of bFGF small interfering RNA reduces STAT3 phosphorylation and induces the depolarization of mitochondria and apoptosis in glioma cells U251 // J. Exp. Clin. Cancer Res.2011.-30-P. 80.

12. Calabrese V., Mallette F. A., Deschenes-Simard X., Ramanathan S., Gagnon J., Moores A., Ilangumaran S., Ferbeyre G. SOCS1 links cytokine signaling to p53 and senescence // Mol. Cell.2009.-36, N 5.-P. 754-767.

13. Miele E., Spinelli G. P., Miele E., Di Fabrizio E., Ferretti E., Tomao S., Gulino A. Nanoparticle-based delivery of small interfering RNA: challenges for cancer therapy // Int. J. Nanomedcine.2012.-7.-P. 3637-3657.

14. Ni Y. H., Wang Z. Y., Huang X. F., Shi P. H., Han W., Hou Y. Y., Hua Z. C., Hu A. Q. Effect of siRNA-mediated downregulation of VEGF in Tca8113 cells on the activity of monocyte-derived dendritic cells // Oncol. Lett.-2012.-3, N 4.-P. 885-892.

15. Gnocchi D., Leoni S., Incerpi S., Bruscalupi G. 3,5,3'-triiodothyronine (T3) stimulates cell proliferation through the activation of the PI3K/Akt pathway and reactive oxygen species (ROS) production in chick embryo hepatocytes // Steroids.-2012.-77, N 6.-P. 589-595.

16. Kim J. H., Kang T. H., Noh K. H., Bae H. C., Ahn Y. H., Lee Y. H., Choi E. Y., Chun K. H., Lee S. J., Kim T. W. Blocking the immunosuppressive axis with small interfering RNA targeting interleukin (IL)-10 receptor enhances dendritic cell-based vaccine potency // Clin. Exp. Immunol..-2011.-165, N 2.-P. 180-189. 